\title{
PERANAN PENGHULU MUKIM DI NANING PADA ZAMAN KOLONIAL BRITISH, 1832-1941
}

\author{
Siti Maisarah Bakar
}

\begin{abstract}
From 1832 Naning was incorporated into Malacca and placed under the Alor Gajah administration. After the British took over the administrative affairs in 1832, it introduced much change though not necessarily reform, on the status quo. Naning was placed directly under the administration of the Resident Councillor of Malacca and the position of the Dato' Penghulu Naning demoted with immediate effect. This articles examine the various change brought about by a change in British policy. The shift of administrative power of Naning to the British witnessed various changes on the administrators and on the Naning people as well. This change of administration also caused the traditional administration of Naning under Dato' Penghulu Naning to be done away with. The abolition of the office of Penghulu of Naning led the British to form a new office: the Penghulu Mukim (District Headman). The British appointed 14 Penghulu Mukims to maintain and preside over the districts under their charge. Each mukim in Naning would have their own appointed district headmen to maintain peace and security in their areas, and these Penghulu Mukims were appointed from among the people within their respective districts.
\end{abstract}

\section{Pengenalan}

Naning merupakan sebuah negeri kecil Melayu yang terletak di antara Rembau (Negeri Sembilan) dengan Melaka. Sejarah dan asal-usul pembukaan Naning dikatakan berkait rapat dengan kehadiran orang Minangkabau ${ }^{3}$ ke negeri tersebut. Naning juga merupakan wilayah 
Minangkabau ${ }^{2}$ yang luasnya adalah kira-kira dua ratus batu persegi atau dua ratus lima puluh kilometer persegi dan jauhnya dari bandar Melaka kira-kira 10 batu. ${ }^{3}$ Sebelum ditakluk oleh British pada tahun 1832, luak Naning adalah bertaraf negeri dan mempunyai kuasa mutlak dengan Penghulu sebagai pemimpin ${ }^{4}$ dan merupakan satu-satunya negeri di Tanah Melayu yang diperintah oleh Penghulu dan dibantu oleh Pembesar Empat Suku. Setelah Naning kalah perang pada 15 Jun $1832,{ }^{5}$ British telah mengugurkan jawatan Penghulu Naning dan menggantikan jawatan tersebut dengan jawatan Penghulu Mukim. Penghulu Mukim merupakan jawatan baru yang diwujudkan oleh British bagi menjalankan kerja-kerja pentadbiran di peringkat mukim.

Penghulu Mukim di Naning merupakan orang yang bertanggungjawab dalam menjaga mukim sesuatu kawasan. Penghulu Mukim merupakan pegawai kerajaan yang dilantik oleh British untuk menjalankan bidang tugas yang telah ditentukan dalam mukim jagaan masing-masing. Oleh itu, penulisan ini ditumpukan kepada peranan Penghulu Mukim di Naning pada zaman kolonial British pada tahun 1832 hingga 1941. Perbincangan akan menjurus kepada pentadbiran dan bidang tugas Penghulu Mukim dalam mukim-mukim jagaannya. Selain itu, perbincangan juga akan menjurus kepada proses perlantikan Penghulu Mukim dan bayaran gaji yang diterima ke atas kerja-kerja yang dijalankan oleh mereka.

\section{Penghulu di Peringkat Mukim}

Setelah mengambil alih pentadbiran Naning secara keseluruhannya, langkah pertama yang diambil oleh British adalah dengan mengugurkan jawatan Penghulu Naning yang selama ini merupakan pemimpin Naning. British telah menafikan hak Penghulu sebagai pemimpin Naning dan British juga tidak mahu Naning terikat dengan pentadbiran Penghulu. Berikutan dengan itu, British telah memecahkan wilayah Naning kepada beberapa mukim bagi memudahkan pentadbiran dijalankan. Kewujudan Mukim-mukim ini adalah untuk memudahkan urusan pentadbiran dijalankan. Sebelum pentadbiran British dijalankan di Naning, pentadbiran dan sistem politik Naning serta pentadbiran adat adalah berdasarkan unit-unit kekeluargaan dan bukannya wilayah atau 'territory'.

Berikutan perubahan ini British telah mewujudkan pentadbiran mukim supaya pentadbiran dapat dijalankan dengan lebih teratur.? Setelah wilayah Naning dipecahkan kepada beberapa buah mukim, British telah melantik seorang Penghulu di setiap mukim. ${ }^{8}$ Pelantikan Penghulu mukim ini dikatakan lebih rendah tarafnya daripada Penghulu Naning yang telah dilucutkan tarafnya setelah Naning jatuh 
ke tangan British. Bidang tugas Penghulu Mukim juga tidak sama seperti Penghulu Naning ketika zaman tradisional dahulu. Setelah beberapa bulan Naning jatuh ke tangan British pada bulan Oktober 1832, Gabenor Robert Ibbetson telah melawat Naning. ${ }^{9}$ Dalam lawatannya itu, beliau telah melantik seramai 15 orang Penghulu bagi mukim-mukim tertentu. ${ }^{10}$ Senarai Penghulu-penghulu Mukim tersebut adalah seperti di bawah:

Jadual 1

Senarai Penghulu Mukim Naning

\begin{tabular}{|llll|}
\hline Bil. & Nama Penghulu & Nama tempat & Suku \\
\hline 1. & Bilal Manja & Ikan Lemak & Batu Belang \\
2. & Mamat & Pikau & Batu Belang \\
3. & Maulana Sultan & Melekek & Batu Belang \\
4. & Safar & Taboh & Semelenggang \\
5. & Kiman & Lendu & Tiga Batu \\
6. & Dol & Ayer Pa'Abas & Anak Melaka \\
7. & Alaudin & Berisu & Anak Melaka \\
8. & Laut & Sungai Siput & Semelenggang \\
9. & Kuroh & Padang Sebang & Tiga Nenek \\
10. & Lengkar & Tanjung Rimau & Tiga Batu \\
11. & Talib & Pulau & Mungkal \\
12. & Udin & Kemuning & Semelenggang \\
13. & Kujal & Batang Melaka & Mungkal \\
14. & ? & ? & $?$ \\
15. & Dul Kunchi & Tebong & Biduanda \\
\hline
\end{tabular}

Sumber: Munsyi Abdullah, Hikayat Abdullah, hlm. 293

Berdasarkan jadual di atas, Abdullah Munsyi menyatakan bahawa terdapat seramai 15 orang Penghulu telah dilantik oleh British. ${ }^{11}$ Pelantikan Penghulu ini adalah mengikut mukim-mukim tertentu dan mewakili mukim-mukim mereka. Dalam Hikayat Abdullah, dinyatakan bahawa Penghulu Mukim yang dilantik adalah seramai 15 orang. Namun, beliau menyatakan hanya seramai 14 orang Penghulu sahaja yang mewakili mukim masing-masing. Manakala pada tahun 1888, turut dinyatakan bahawa hanya 14 buah mukim sahaja yang didaftarkan di daerah Utara Melaka. ${ }^{12} \mathrm{Hal}$ ini menunjukkan bahawa, 
hanya 14 orang Penghulu Mukim sahaja yang dilantik dan bukannya 15 orang seperti yang dinyatakan oleh Abdullah.

\section{Pelantikan Penghulu Mukim}

Pelantikan Penghulu Mukim adalah berdasarkan kepada faktor keselamatan dan keamanan sesebuah kawasan. Oleh sebab itu, British melantik Penghulu Mukim bukan dalam kalangan Pembesar Naning yang sebelum ini. British melantik Penghulu Mukim hanya dalam kalangan orang-orang tua Naning dan bukannya dalam kalangan mereka yang berstatus tinggi iaitu dari ketua-ketua suku dahulu. British bertindak sedemikian kerana ingin menjamin keselamatan dan keamanan Naning. British bimbang sekiranya melantik Penghulu Mukim dalam kalangan ketua-ketua suku yang mentadbir Naning sebelum ini, akan melahirkan kembali semangat penentangan penduduk kepada British. British juga sedar bahawa pengaruh Pembesar-pembesar Naning sebelum ini sangat besar dan mereka ini akan menggugat kedudukan British di Naning. Berikutan itu, British bertindak dengan melantik Penghulu Mukim dalam kalangan mereka yang mengikut telunjuk British bagi menjamin keamanan di Naning. Penghulu Mukim yang baru dilantik ini sepenuhnya berada di bawah pengawasan dan kawalan British.

Pelantikan Penghulu Mukim ini secara langsung telah menghapuskan kuasa tradisi Penghulu Naning dan Pembesar Empat Suku. ${ }^{13}$ Malah, pelantikan Penghulu-penghulu Mukim ini juga telah menyebabkan Gabenor Robert Ibbetson memecat Pembesar Empat Suku yang menentang British ketika perang berlangsung. ${ }^{14}$ Pembesar Empat Suku yang dipecat ialah Datuk Membangun dari suku Tiga Batu, Datuk Andika Maharaja dari suku Anak Melaka, Datuk Raja Nankaya dari suku Semelenggang dan Datuk Orang Kaya Kechil dari suku Mungkal. ${ }^{15}$

Selain itu, Pelantikan Penghulu Mukim adalah bagi menggantikan Pembesar Empat Suku yang telah dipecat kerana membantu Dato' Dul Said dalam Perang Naning menentang British. British memecat Datuk Empat Suku kerana mereka mempunyai pengaruh yang kuat dalam kalangan masyarakat Naning. Mereka telah memimpin penduduk di mukim masing-masing untuk menyerang pasukan British yang melalui kawasan mereka. ${ }^{16}$ Oleh itu, mereka dipecat oleh British su paya keamanan boleh dijaga di Naning kerana British bimbang sekiranya Datuk-datuk Empat Suku ini masih mempengaruhi penduduk di mukim masing-masing supaya menentang British.

Pelantikan 14 orang Penghulu Mukim oleh British adalah untuk menjalankan pentadbiran dan menguruskan segala urusan di peringkat 
mukim. ${ }^{17}$ Kesemua Penghulu Mukim ini adalah di bawah arahan Pesuruhjaya Naning iaitu Mr. Westerhout dan taraf mereka juga adalah sama di Wilayah Naning. ${ }^{18}$ Pelantikan Penghulu Mukim ini telah menjatuhkan martabat Dato' Naning sebagai Penghulu Naning sebelum ini. British telah menggantikan jawatan Penghulu ini dengan mewujudkan jawatan Penghulu Mukim dan menaik taraf jawatan tersebut. Malah, Penghulu Mukim ini hanya berkuasa dalam mukim yang ditetapkan sahaja ${ }^{19}$ dan berperanan dalam menyampaikan perintah British kepada penduduk mukim. British mewujudkan jawatan Penghulu Mukim adalah untuk memudahkan tugas mereka dalam urusan pentadbiran di peringkat mukim.

Jawatan Penghulu Mukim telah dapat diterima oleh penduduk mukim sebagai salah satu jawatan tradisi. ${ }^{20}$ Penghulu Mukim ini dilantik di mukim tempat asalnya dan bertugas dalam mukimnya kerana mereka ini bertugas dalam kalangan penduduk di dalam mukimnya sahaja. Pelantikan Penghulu Mukim berdasarkan mukim yang diduduki oleh mereka bertujuan supaya Penghulu Mukim ini lebih rapat dengan anak-anak buahnya (Penduduk dalam sesuatu mukim). Pelantikannya juga kerana mereka lebih memahami dan mengetahui latar belakang serta tingkah laku anak buahnya. Penghulu Mukim akan menyampaikan segala arahan dan perintah yang dikeluarkan oleh British terus kepada anak buahnya tanpa melalui peringkat yang lain kerana beliau sendiri mengenali anak-anak buahnya secara rapat. ${ }^{21}$ Dengan sistem ini, secara langsung dapat membantu untuk mempermudahkan tugas dan peranan Penghulu Mukim itu sendiri ketika menjalankan arahan-arahan yang dikeluarkan oleh British kepada anak buahnya. Pelantikan Penghulu Mukim dalam kalangan penduduk mukim itu sendiri juga bertujuan supaya masyarakat mukim tidak melawan atau membantah kerja-kerja yang dilakukan oleh Penghulu Mukim terhadap mereka. Penghulu Mukim merupakan pegawai yang dilantik untuk menjalankan pentadbiran dalam mukim-mukim yang telah ditentukan. ${ }^{22}$

Pelantikan dan pemilihan Penghulu Mukim tidak dilakukan dengan mudah dan cepat. Pemilihan jawatan ini adalah mengikut adat. Pada peringkat awal, Penghulu Mukim dilantik oleh Gabenor British di Melaka. ${ }^{23}$ Apabila seseorang Penghulu Mukim bersara, meninggal dunia atau dipecat, Pegawai Daerah akan menyediakan tempat untuk berkumpul. Pemilihan jawatan Penghulu Mukim ditentukan melalui dua cara. Pertama, Pegawai Daerah akan yang menentukan suku yang berhak kepada jawatan tersebut. Kedua, suku yang berhak mencadangkan calon-calon untuk dipilih daripada suku tersebut. Calon-calon yang telah dicadangkan ini, kemudiannya akan ditapis 
sehingga tinggal tiga hingga empat calon untuk pemilihan jawatan Penghulu Mukim tersebut. Kebiasaannya, anak buah akan mempersetujui cadangan yang telah dibuat oleh Pegawai Daerah. Calon-calon yang diutamakan ialah mereka yang boleh menulis dan membaca serta kerap bersembahyang di masjid. Manakala calon-calon yang tidak berkelayakan seperti lemah fizikal (sudah berumur), lemah akal, pernah berkelakuan keji dan orang ramai tidak berpuas hati dengan pemilihannya akan diketepikan. Calon-calon yang telah dipilih dan ditapis akan dirahsiakan oleh Pegawai Daerah sehingga dipersetujui oleh Residen kerana Penghulu Mukim yang baru akan dilantik oleh Residen. ${ }^{24}$

Mulai tahun 1930, pemilihan jawatan Penghulu Mukim tidak lagi dilantik oleh British kerana pemilihan untuk jawatan Penghulu Mukim ini telah diserahkan kepada penduduk mukim itu sendiri. Malah, pemilihan jawatan Penghulu Mukim juga diserahkan kepada penduduk mukim walaupun Pegawai Daerah mempunyai kuasa dalam pengesahan jawatan tersebut. Pemilihan ditentukan oleh penduduk mukim sendiri kerana hanya mereka sahaja yang mengenali bakal Penghulu Mukim mereka bukan sahaja dari segi budi bahasa tetapi juga dari segi kebolehan dan keupayaan dalam menjalankan tugastugas yang telah diperintahkan. Dalam pemilihan jawatan ini juga, penduduk mukim telah bersetuju supaya pemegang jawatan Penghulu Mukim mestilah mengikut giliran suku. ${ }^{25}$ Namun, tidak semua mukim di Naning mengamalkan pemilihan Penghulu Mukim berdasarkan kepada giliran suku. Terdapat juga pemilihan Penghulu Mukim yang berdasarkan pengundian rahsia dan juga secara terbuka. Pemilihan cara ini adalah tidak mengikut giliran suku. Keputusan pengundian adalah tertakluk kepada pengesahan "Resident Commissioner". ${ }^{26}$ Penghulu Mukim yang baru akan diberikan surat kuasa, cop, tali pinggang dan kayu belantan polis dan sepasang gari. ${ }^{27}$

\section{Peranan dan Bidang Tugas Penghulu Mukim}

Kedudukan Penghulu Mukim dalam pentadbiran kolonial adalah penting. Walaupun kedudukannya lebih rendah dari Demang dalam struktur pentadbiran yang diwujudkan oleh pihak British namun, peranannya sangat penting dalam menguruskan pentadbiran di peringkat mukim. ${ }^{28}$ Penghulu Mukim merupakan ketua yang menjaga segala kebajikan mukim dan menjalankan segala kerja pentadbiran yang telah diarahkan oleh British. Pegawai British iaitu Pegawai Daerah yang merupakan pentadbir kawasan daerah dan memantau mukim-mukim di bawah jagaannya akan mengeluarkan arahan kepada Penghulu Mukim berkaitan tugas-tugas yang perlu dilaksanakannya 
kepada penduduk mukim. Dengan arahan yang dikeluarkan ini, Penghulu Mukim akan menyampaikan arahan tersebut kepada penduduk mukim supaya arahan-arahan dari Pegawai Daerah ini sampai kepada mereka. Penghulu Mukim ini bertanggungjawab melaporkan kepada Pegawai Daerah setiap arahan yang telah dikeluarkan. Dalam erti kata lain, Penghulu Mukim ialah pegawai kerajaan yang bekerja di bawah kerajaan negeri Melaka dan segala urusan yang dilakukan adalah atas nama kerajaan..$^{29}$ Penghulu Mukim juga merupakan penolong atau pembantu kepada kerajaan ${ }^{30}$ dalam menjalankan kerja-kerja pentadbiran di peringkat mukim.

Bidang kuasa Penghulu Mukim adalah tidak sama dengan bidang kuasa Penghulu Naning dahulu. Walaupun jawatan Penghulu Naning telah dimansuhkan oleh British, namun Penghulu Mukim ini hanya berkuasa dalam mukimnya sahaja dan kuasa ini hanyalah terhad kepada bidang-bidang kuasa yang telah ditetapkan oleh British sahaja. Pelantikan Penghulu Mukim adalah bertentangan dengan jawatan dan kuasa Lembaga dalam susunan adat dan tadbiran mukim kerana Penghulu Mukim dan Lembaga berkuasa dalam suatu kawasan yang sama atau hampir sama. Hal ini kerana Penghulu Mukim ialah Ketua Unit Wilayah manakala Lembaga adalah Ketua Unit Sosial. Oleh yang demikian, bagi mengelakkan wujudnya konflik antara keduanya, British telah menggugurkan kedudukan Lembaga lebih rendah daripada Penghulu Mukim dan hanya Penghulu Mukim dianggap sebagai kuasa tempatan (local authority) dalam hal adat dan tadbiran awam di dalam sesebuah mukim. ${ }^{31}$.

Bagi melaksanakan segala tugas yang diperintahkan oleh British maka, jawatan Penghulu Mukim ini diwujudkan supaya pentadbiran mukim di Naning dijalankan dengan lebih teratur. Penghulu Mukim dilantik berdasarkan gelaran antara suku-suku yang terdapat dalam sesebuah mukim. ${ }^{32}$ Pelantikan Penghulu Mukim adalah berdasarkan susunan adat iaitu suku supaya tidak memisahkan Penghulu Mukim tersebut dari kenyataan sosial di sekelilingnya. Kedudukannya juga adalah berdasarkan susunan masyarakatnya. ${ }^{33}$ Bagi menjalankan pentadbirannya dalam sesebuah mukim, Penghulu Mukim menerima arahan daripada Pegawai Daerah. Pegawai Daerah akan mengeluarkan perintah dan arahan kepada setiap Penghulu Mukim berkaitan dengan bidang tugas mereka dan tindakan-tindakan yang sepatutnya dijalankan terhadap mukim masing-masing. Pegawai Daerah yang memegang tampuk pemerintahan dalam daerah Alor Gajah akan mengeluarkan arahan kepada Penghulu Mukim bagi menyampaikan sebarang maklumat atau perintah British kepada masyarakat disesebuah mukim. Penghulu Mukim dianggap sebagai 
pekerja kerajaan dan bertindak sebagai penghubung rasmi antara masyarakat dalam mukimnya dengan kerajaan British melalui peraturan-peraturan yang telah ditetapkan oleh pihak kerajaan. ${ }^{34}$ Penghulu Mukim hanya berperanan dalam menjalankan tugas dalam mukimnya sahaja. Jawatan Penghulu Mukim juga diwujudkan untuk menjaga keamanan dan kemakmuran ${ }^{35}$ serta melindungi anak-anak buahnya dalam mukim masing-masing. ${ }^{36}$

Peranan Penghulu Mukim sangat penting dalam mewujudkan perhubungan antara pihak pemerintah dengan penduduk dalam mukimnya. Penghulu Mukim bukan sahaja berperanan sebagai ketua mukim malah berperanan dalam beberapa hal yang berkaitan dengan pentadbiran seperti menguruskan hal-hal yang berkaitan dengan kebajikan kampung iaitu menentukan musim penanaman padi, membuat bancian penduduk dan hal-hal umum seperti kesihatan dan kebersihan. Selain itu, Penghulu Mukim juga bertanggungjawab dalam menyimpan segala senarai umur, kelahiran, kematian dan perkahwinan anak buahnya ${ }^{37}$ Penduduk mukim boleh mendaftarkan kelahiran dan kematian kepada Penghulu Mukim sekiranya tidak mendaftarkannya di balai polis ${ }^{38}$ Semua aduan di mukim masing-masing juga perlu dibuat kepada Penghulu Mukim. ${ }^{39}$ Pada peringkat awal pemilihannya, Penghulu Mukim ini berperanan menjadi ketua mukim dengan mengawasi keamanan mukimnya.

Penghulu Mukim berperanan sebagai pentadbir keamanan dalam mukimnya. ${ }^{40}$ Dengan tugas yang diberikan, Penghulu Mukim akan memastikan keamanan dan kesejahteraan mukim yang berada di bawah kawalannya ${ }^{41}$ Penghulu Mukim diharapkan menggunakan usaha mereka untuk mempertahankan ketenteraman awam. ${ }^{42}$ Mereka akan menjaga keamanan kampung daripada berlakunya sebarang pergaduhan dan kacau bilau yang ditimbulkan oleh anak buahnya. Sekiranya berlaku jenayah kecil seperti pergaduhan kecil dalam kalangan anak buahnya, Penghulu Mukim sendiri yang akan menyelesaikan masalah tersebut. ${ }^{43}$ Penghulu Mukim mempunyai kuasa untuk mengadakan mahkamah Penghulu untuk menyelesaikan keskes kecil yang berlaku dalam kalangan anak buahnya. Penghulu Mukim boleh mengenakan denda dengan jumlah tertentu dalam perkara sivil yang kecil kepada anak buahnya. ${ }^{44}$ Manakala, sekiranya berlaku keskes yang berat di dalam mukim jagaannya, Penghulu Mukim hendaklah memberi maklumat berkenaan kes tersebut ${ }^{45}$ kepada Pegawai Daerah dan membawa kes tersebut ke Melaka serta menyerahkannya kepada kerajaan negeri Melaka untuk diadili dan bukan lagi kepada Penghulu atau Empat Suku ${ }^{46}$ seperti ketika zaman pentadbiran tradisional. Keskes berat seperti kes jenayah akan diadili di mahkamah Melaka. 
Penghulu Mukim juga dikehendaki melaporkan setiap perilaku penduduk kepada kerajaan British ${ }^{47}$ bagi menjamin keamanan mukim berterusan.

Selain menyelesaikan masalah jenayah yang kecil dalam kalangan penduduk mukim, Penghulu Mukim juga ditugaskan untuk menangkap orang yang melakukan jenayah dan menghadapkan pesalah tersebut kepada kerajaan di Melaka untuk diadili. ${ }^{48}$ Dalam usaha untuk menangkap pesalah, Penghulu Mukim dikehendaki mematuhi arahan polis dan sekiranya tugas tersebut tidak dapat dilakukan dengan Matamata, maka Penghulu boleh meminta bantuan daripada penyewa. ${ }^{49}$ Penghulu Mukim hanya boleh menahan pesalah di dalam kurungan tidak melebihi 24 jam $^{50}$ dan tidak dibenarkan mengadili sebarang kes jenayah berat. British telah memutuskan bahawa Penghulu Mukim hanya boleh menjatuhkan hukuman dan mengenakan denda kepada pesalah kepada kes-kes kesalahan yang kecil tetapi sekiranya berlaku kes jenayah yang berat seperti pembunuhan, kes tersebut hendaklah diserahkan kepada kerajaan negeri Melaka untuk diadili dan diambil tindakan yang selanjutnya.

Dalam bidang tugas menjaga keamanan mukim ini, Resident Councillor Melaka mengarahkan Penghulu Mukim memberi maklumat penjenayah kepada polis, melaporkan pencerobohan tanah kerajaan dan menyekat pergaduhan di mukim masing-masing. ${ }^{51}$ Dalam kes menjaga keamanan mukim, Penghulu Mukim bersama-sama Majlis Mukim dan Mata-mata mewujudkan dan menjaga keamanan mukim mereka dengan menyelesaikan sebarang pergaduhan yang berlaku dalam mukim tersebut dan bertindak sebagai mahkamah dalam hal yang berkaitan dengan anak-anak buahnya berkaitan dengan kes jenayah yang kecil.52

Penghulu Mukim hanya berkuasa dalam mukimnya sendiri terhadap ketenteraman, keamanan dan hubungan baik antara anakanak buah. Penghulu Mukim sebenarnya mempunyai hubungan yang nyata dan tepat dengan orang ramai dan mempunyai saluran tepat bagi British ${ }^{53}$ untuk menggunakan khidmat Penghulu Mukim dalam menyampaikan segala arahan dan suruhan British kepada penduduk di setiap mukim. Dengan dipertanggungjawabkan untuk menjaga keamanan dan ketenteraman mukimnya, Penghulu Mukim terpaksa bertindak dan bersikap baik dengan pemerintah kolonial. Penghulu Mukim juga berperanan dalam menyampaikan segala keadaan tidak puas hati atau gelisah masyarakat mukim kepada pemerintah kolonial untuk diambil tindakan seterusnya oleh British. ${ }^{54}$ Dengan kata lain, Penghulu Mukim berperanan sebagai orang tengah atau perantara antara penduduk mukim dengan pegawai British. Dalam menjalankan 
kerja-kerja dalam mukim jagaannya, Penghulu Mukim bertanggungjawab kepada Pegawai Daerah. ${ }^{55}$

Selain menjaga ketenteraman dan keamanan kampung daripada berlakunya sebarang jenayah dalam kalangan masyarakatnya, Penghulu Mukim juga berperanan dalam membantu kerajaan dalam soal tanah ${ }^{56}$ dan memungut hasil dalam mukim masing-masing. ${ }^{57}$ Peranan Penghulu Mukim dalam soal tanah merupakan tugas utama yang perlu diberi perhatian. ${ }^{58} \mathrm{Di}$ sini, Penghulu Mukim berperanan dalam memberitahu atau memberi amaran kepada anak-anak buahnya yang tidak membayar cukai dan tentang masa pembayaran cukai yang perlu dilakukan di Pejabat Daerah. Hal ini penting kerana hasil cukai yang didapati dari mukimnya adalah menjadi penentu kepada jumlah bayaran sagu hati yang akan diperolehinya sepanjang beliau menjalankan tugas tersebut. ${ }^{59}$ Dalam urusan memungut hasil ini, adalah menjadi kebiasaan apabila anak buah meminta bantuan Penghulu Mukim untuk membayar cukai di Pejabat Daerah. Hal ini disebabkan masyarakat tempatan kurang memahami selok-belok urusan di pejabat, tambahan pula ramai dalam kalangan mereka adalah buta huruf. Terdapat juga dalam kalangan mereka yang berpendapat bahawa lebih senang sekiranya urusan pembayaran cukai di Pejabat Daerah diserahkan kepada Penghulu Mukim daripada mereka yang melibatkan diri kerana mereka tidak mahu meninggalkan kerja-kerja harian mereka. ${ }^{60}$ Dengan perlunya membayar cukai di Pejabat Daerah, masyarakat tempatan terpaksa meninggalkan kerja harian mereka. Pembayaran cukai tersebut memakan masa dan ada kalanya mereka terpaksa melalui perjalanan yang jauh untuk ke Pejabat Daerah. Berikutan dengan itu, mereka lebih senang menyerahkan pembayaran cukai ke Pejabat Daerah dilaksanakan oleh Penghulu Mukim. Penghulu Mukim dikehendaki ke Pejabat Daerah setiap hari Isnin, Selasa dan Rabu. ${ }^{61}$ Penghulu Mukim ke Pejabat Daerah untuk mendapatkan arahan daripada Pegawai Daerah dan juga untuk menyampaikan beberapa masalah yang berkaitan dengan pentadbiran mukim. Di samping itu, Penghulu Mukim juga ke Pejabat Daerah untuk mewakili penduduk mukim untuk membayar cukai bagi pihak mereka.

Hubungan Penghulu Mukim dengan anak buahnya adalah sangat rapat. Hal ini dapat digambarkan ketika urusan pembayaran cukai dibuat. Newbold sendiri menyatakan bahawa:

When the grain is ripe, a person on the part of Government visits the rice-fields, attended by the owner, the Penghulu, or Mata Matas of the village, and several of the oldest inhabitants, on the sport, in order to agree upon and assess the value of the crop. A difference of opinion will naturally sometimes arise between the taxer and 
the taxer. This is submitted to the arbitration of the Penghulu and the village elders. ${ }^{62}$

Dalam soal tanah dan kutipan cukai, Penghulu Mukim sangat diperlukan dalam menyelesaikan perbalahan antara anak-anak buah yang sering berlaku di dalam sesebuah mukim. ${ }^{63} \mathrm{Hal}$ ini kerana Penghulu Mukim yang menguruskan hal-hal yang berkaitan dengan tanah. Pengurusan tanah ini bermaksud menguruskan hal-hal yang berkaitan dengan tanah pusaka. Dalam hal ini, Penghulu Mukim terlibat dalam urusan penukaran kuasa dalam geran tanah pusaka dan perbicaraan mengenai perwarisan tanah pusaka sekiranya perwarisan harta tanah pusaka tersebut tidak dapat diselesaikan antara waris-waris yang berkaitan. Peranan Penghulu Mukim dalam hal ini hanyalah sekadar memberitahu dan memberi ingatan berkaitan tarikh perbicaraan kepada pihak-pihak yang terlibat mengenai surat-surat atau dokumen yang perlu dibawa ke Pejabat Daerah sekiranya mereka mempunyai urusan di Pejabat Daerah. ${ }^{64}$

Dalam menjalankan pentadbiran dalam sesebuah mukim, terutamanya dalam soal yang berkaitan dengan tanah, Penghulu Mukim akan bekerjasama dengan Sidang. Sekiranya terjadi perbalahan antara dua orang tentang pemilikan sebidang tanah dan kedua-dua pihak yang berbalah tersebut berlainan suku, Penghulu Mukim akan terus menemui kedua-dua belah pihak tanpa bantuan daripada Sidang. Tetapi tugas ini akan lebih mudah sekiranya Penghulu Mukim mengumpulkan Sidang di kedua-dua belah suku dari pihak yang berbalah serta mencari jalan penyelesaian. Bantuan Sidang diperlukan kerana Sidang lebih memahami ahli-ahli di kalangan sukunya. ${ }^{65}$

Penghulu Mukim juga turut berperanan dalam urusan adat. Malah, segala keputusan dan tindakan yang di luar dari tugas pentadbiran adalah diselesaikan berdasarkan saluran atau aturan adat. Dalam urusan adat ini juga, Penghulu Mukim mendapat kerjasama daripada Sidang (Lembaga). ${ }^{66}$ Berikutan jawatan Penghulu Naning telah dihapuskan oleh British, maka urusan yang berkaitan dengan adat ini diserahkan kepada Penghulu Mukim. British tidak campur tangan dalam segala hal yang berkaitan adat. British berpendapat bahawa, urusan adat adalah urusan masyarakat tempatan sejak dahulu lagi dan British tidak mahu campur tangan dalam urusan yang melibatkan soal budaya masyarakat setempat. Dengan ini, Adat Perpatih di Naning kekal dan berjalan di bawah Penghulu yang dipilih. Sebagai ketua mukim yang berperanan dalam adat, Penghulu Mukim turut berperanan dalam upacara nikah kahwin kerana Penghulu Mukim menjadi tonggak untuk mengatur dan menyusun upacara perkahwinan itu supaya sesuai dengan keadaan masyarakat setempat. ${ }^{67}$ Namun, 
Penghulu Mukim yang merupakan pegawai kerajaan tidaklah sepenuhnya sebahagian daripada perlembagaan adat tradisional. ${ }^{68} \mathrm{Di}$ daerah Alor Gajah ini (sebahagian besar terdiri daripada Luak Naning) menunjukkan bahawa Penghulu secara separa elektif masih lagi berkait langsung dengan struktur adat.$^{69}$ Setelah jawatan Dato' Penghulu Naning diwujudkan kembali oleh British pada tahun 1850, urusan berkaitan dengan Adat Perpatih Naning kembali dipegang oleh Penghulu Naning.

Selain menjalankan kerja-kerja pentadbiran, Penghulu Mukim juga berperanan untuk menggalakkan masyarakat di mukimnya bercucuk tanam dan menjalankan kerja-kerja sawah serta ladang. Penghulu Mukim diberi tugas untuk menentukan waktu untuk turun ke sawah dan menyemai anak benih. ${ }^{70}$ Bidang tugas yang dilakukan oleh Penghulu Mukim ini menunjukkan bahawa seorang Penghulu itu bukan sahaja berperanan dan menjaga keamanan mukim malah turut menjaga kebajikan penduduknya. Penghulu Mukim juga turut memastikan penduduknya hidup dengan rukun damai dan harmoni. Dalam hal ini, pernah terjadi Penghulu Mukim berperanan sebagai seorang polis. Mereka diberi tali pinggang polis secara percuma dan lima biji butang rasmi serta gaji yang biasa digunakan oleh polis pada ketika itu. ${ }^{71}$ Penghulu Mukim adalah orang yang bertanggungjawab dalam menjalankan kerja-kerja pentadbiran dalam mukimnya. Namun begitu, terdapat juga Penghulu Mukim yang dipecat daripada jawatannya kerana telah berlaku tidak jujur, sudah terlalu tua dan tidak pandai. Sehingga tahun 1891, terdapat seramai 28 orang Penghulu Mukim di daerah Alor Gajah. ${ }^{72}$ Kesemua 28 orang Penghulu Mukim yang dilantik dalam daerah Alor Gajah ini adalah bertanggungjawab kepada mukim masing-masing. Pelantikan mereka adalah untuk menguruskan hal-hal yang berkaitan dengan kebajikan anak buah, pungutan cukai dan keselamatan mukim. Dalam kalangan Penghulu Mukim ini, dilantik juga seorang ketua yang dikenali sebagai Demang. Pada tahun 1891, seramai lima orang Demang dilantik. Mereka berasal dari mukim Taboh Naning, Kelemak, Pulau Sebang, Sungei Baru Tengah dan Beringin. Inche Matsaleh bin Bidin dilantik sebagai ketua Demang. ${ }^{73}$ Pelantikan beliau menunjukkan bahawa British masih lagi mengutamakan mereka yang berasal dari Taboh Naning kerana menghormati Penghulu Naning yang sebelum ini berkuasa dalam luak Naning.

Penghulu-penghulu Mukim yang dilantik ini biasanya menjalankan kerja yang diperintahkan oleh Pegawai Daerah dengan baik. Kerja-kerja yang dijalankan oleh mereka sangat berguna kepada Rural Board yang baru ditubuhkan. ${ }^{74}$ Bagi membantu tugas-tugas 
Penghulu mukim menjalankan kerja-kerja pentadbiran di mukimnya, Penghulu Mukim ini dibantu oleh seorang pembantu yang dikenali sebagai Mata-mata. ${ }^{75}$ Mata-mata yang baik sangat diperlukan dalam sebuah mukim yang ramai penduduk. ${ }^{76}$ Pelantikan Mata-mata adalah sebagai pengiring atau pegawai keselamatan kepada Penghulu Mukim. Mata-mata dilantik oleh Residen dengan sokongan daripada Penghulu Mukim $^{77}$ dan bertanggungjawab sepenuhnya kepada Penghulu. Matamata yang dipilih adalah mereka yang memihak kepada kerajaan British. Robert Ibbetson menegaskan bahawa:

It will not only be advisable but indispensable, not to select the Mata-mata from among persons of influences who have been engaged actively against 'Government'. ${ }^{78}$

Seorang Mata-mata biasanya berkhidmat bagi seorang Penghulu Mukim. Tanggungjawab Mata-mata adalah sama seperti polis tetapi mereka bukanlah polis. Mata-mata ini biasanya membantu Penghulu Mukim dalam urusan yang berkaitan dengan pentadbiran dan juga kutipan cukai. Hal ini kerana, pemilihan Penghulu Mukim tidak dilakukan berdasarkan kebolehannya dalam urusan berkaitan pungutan cukai. Biasanya tugas-tugas ini akan diserahkan kepada Mata-mata kerana Mata-mata yang dilantik ketika itu merupakan golongan terpelajar dalam kalangan penduduk kampung kerana mereka mempunyai kebolehan membaca, menulis dan mengira. ${ }^{79}$ Kemahiran ini digunakan Mata-mata untuk mereka mendaftarkan kelahiran dan juga kematian yang berlaku di sesebuah mukim. Tugastugas ini dijalankan oleh Mata-mata kerana kebanyakan Penghulu Mukim tidak tahu membaca dan menulis. ${ }^{80}$ Selain itu, Mata-mata juga berperanan dalam membantu Penghulu Mukim untuk menjaga keamanan mukim dan menyelesaikan pergaduhan kecil di dalam mukim. Sekiranya berlaku kes-kes jenayah, Mata-mata akan ditugaskan menangkap pesalah dan membawa pesalah tersebut ke mahkamah di Melaka. ${ }^{81}$ Selain membantu Penghulu Mukim, Mata-mata juga berperanan dalam membantu guru-guru mengutip derma. ${ }^{82}$ Penghulu Mukim dan Mata-mata yang bergandingan bersama dalam menjaga mukim-mukim tertentu, tidak boleh dari kalangan suku yang sama. ${ }^{83}$

\section{Bayaran Gaji Penghulu Mukim dan Mata-mata}

Pada peringkat awal, Penghulu Mukim tidak menerima sebarang upah atau gaji ${ }^{84}$ tetapi mereka dikecualikan daripada membayar cukai tanahnya sendiri. Penghulu Mukim juga tidak boleh mengumpul pendapatan sendiri ${ }^{85}$ sebaliknya mereka memperoleh pendapatan daripada sagu hati yang diterima daripada kutipan cukai yang 
diperolehi. Dengan pendapatan yang diperolehi ini, memberikan daya penarik kepada Penghulu Mukim untuk menjalankan tugas dengan bersungguh-sungguh dan memaksa anak-anak buahnya menjelaskan cukai pada waktu yang telah ditetapkan. ${ }^{86}$ Pada tahun 1890 , sistem Demang dan Penghulu diharapkan dapat dilengkapkan secepat mungkin dan beberapa imbuhan dapat diberikan kepada Penghulu Mukim untuk pampasan ke atas kehilangan yuran satu persepuluh yang diperoleh oleh mereka di bawah sistem satu persepuluh. ${ }^{87}$ Sebelum ini, Penghulu memperoleh pendapatan melalui cukai yang diperolehi daripada penduduk. Namun, setelah pengambil alihan pentadbiran Naning, mereka tidak lagi dibenarkan untuk berbuat demikian. Oleh itu, dicadangkan supaya Demang dan Penghulu Mukim diberi bayaran ke atas tugas-tugas yang laksanakan oleh mereka. Begitu juga dengan Mata-mata. Mereka tidak menerima sebarang upah tetapi tanahnya dikecualikan daripada cukai. ${ }^{88}$

Mulai tahun 1870, Penghulu Mukim dan Mata-mata diberi lima peratus daripada keseluruhan cukai tanah apabila pembayaran telah dibuat oleh penduduk mukim di Pejabat Tanah. Mereka juga mendapat sepuluh peratus komisyen daripada hasil barangan seperti ubi kayu, gambir dan hasil hutan. Elaun sebanyak 45 sen sehari juga diberikan apabila mereka bertugas di luar iaitu bagi menentukan sempadan tanah dan menilai hasil di sawah. Mereka juga dikecualikan daripada membayar cukai tanah dan bayaran hasil tanah dihadkan kepada 10 ekar untuk Penghulu dan lima ekar untuk Mata-mata. ${ }^{89}$

Mulai tahun 1882, Penghulu Mukim dan Mata-mata dicadangkan supaya dibayar gaji. ${ }^{90}$ Pembayaran gaji kepada Penghulu Mukim hanya dibuat pada tahun 1888. Mereka telah diberi gaji sebanyak $\$ 5.00$ sebulan $^{91}$ dan ditambah elaun sebanyak $\$ 2.00$ menjadikan gaji Penghulu Mukim pada waktu iaitu ialah sebanyak $\$ 7.00 .{ }^{92}$ Pertambahan ini membolehkan Penghulu Mukim lebih bersungguh-sungguh dalam memberi perhatian kepada mukim mereka. ${ }^{93}$ Jumlah gaji sebanyak $\$ 5.00$ sebulan adalah tidak cukup jika dibandingkan dengan tugas yang jalankan oleh mereka di mukim masing-masing. ${ }^{94}$ Berikutan dengan ini, selepas tahun 1900, gaji Penghulu Mukim dinaikkan kepada $\$ 7.00$ sebulan dan seterusnya meningkat kepada $\$ 8.00$ sebulan pada tahun $1904 . .^{95}$ Selain menerima bayaran gaji sebanyak $\$ 8.00$, mereka juga menerima bonus tahunan sebanyak $\$ 30.00 .{ }^{96}$ Pembayaran gaji Penghulu Mukim ini sentiasa meningkat sehinggalah pembayaran gaji ini meningkat kepada $\$ 30.00$ sebulan pada tahun $1941 .{ }^{97}$ Pada tahun 1905, semua Penghulu Mukim diberi bonus tahunan, ${ }^{98}$ begitu juga pada tahun $1907^{99}$ dan $1980^{100}$ kerana mereka telah menjalankan kerja dengan baik. ${ }^{101}$ Pembayaran bonus kepada Penghulu Mukim adalah daripada 
peratusan tertentu dari penilaian mukim yang telah dikumpulkan. ${ }^{102}$ Selain bayaran gaji dan bonus kepada Penghulu Mukim, pada tahun 1882, dicadangkan supaya mata-mata dibayar gaji ${ }^{103}$ di atas perkhidmatan yang jalankan oleh mereka. Pada tahun 1897, selain diberi gaji dicadangkan juga supaya Mata-mata diberi bonus di atas kerja-kerja yang jalankan oleh mereka. ${ }^{104}$

\section{Kesimpulan}

Peranan Penghulu Mukim dan Mata-mata dalam sesebuah mukim adalah sangat penting untuk menggantikan tugas dan peranan yang sebelum ini dilaksanakan oleh Penghulu Naning dan Pembesar Empat Suku. Penghulu Mukim dan Mata-mata diletakkan di bawah pengawasan Pegawai Daerah dan segala tugas yang dilakukan adalah di atas arahan Pegawai Daerah. Walaupun jawatan Penghulu Naning diwujudkan kembali pada tahun 1850, namun Penghulu Naning hanya berkuasa dalam adat sahaja dan bukan lagi sebagai pemimpin dan peguasa luak Naning. Penghulu Mukim hanya berkuasa dalam 25 buah mukim dan dalam pentadbiran adat sahaja. Tugas-tugas pentadbiran mukim akan dijalankan oleh Penghulu Mukim di bawah arahan Pegawai Daerah.

\section{Nota}

1 Orang Minangkabau merupakan penduduk asal kawasan yang kini dikenali sebagai Sumatera Barat di Indonesia. Orang Minangkabau ialah orang Melayu memandangkan bahasanya yang hampir sama. Ramai pengkaji Barat misalnya pengkaji Belanda menganggap orang Minangkabau sebagai Melayu. Sebuah Tambo Minang menulis tentang asal-usul nama Minangkabau iaitu dari kemenangan lagu kerbau dengan tentera Majapahit. Lihat, Datoek Batoeh Sago, Tambo Alam Minangkabau, Pajakumbuh: Pencetakan Limbago, hlm. 57-59.

$2 \quad$ R. O. Winstedt (ed.), Malaya: The Straits Settlements and The Federated and Unfedereted Malay State, London: Constable and Co. Ltd., 1923, hlm. 143.

$3 \quad$ L.A. Mills, "The Naning War", British Malaya 1824-67, JMBRAS, Reprint No. 22-2003, hlm. 137. Rujuk juga Dato Dr. Mohd Rosli Saludin, Naning Luak Terbilang, Penang: Goalintelligent Publishing Sdn. Bhd., 2007, hlm. 1; Jonathan Cave, Naning in Melaka, JMBRAS, Monograph No. 16, 1996, hlm. 3.

4 Koleksi Pameran Raja Berdaulat, Negeri Beradat, Kuala Lumpur: Arkib Negara Malaysia, 2004, hlm. 32.

5 C. O. 273/1, "Chapter 3 VIII- Malacca Naning War", Straits Settlements Original Corresponden, hlm. 410. Lihat juga, IOR. V. 368. BSC., Kolonel Herbert kepada Residen Konsular Melaka, 16 Jun 1832.

6 Zainal Kling, “Adat Minangkabau di Naning (Melaka): Beberapa Perubahan Struktur", dalam Abdul Latif Abu Bakar, Sejarah di Selat Melaka, Melaka: Persatuan Sejarah Malaysia, 1984, hlm. 85. 
Terdapat 67 buah mukim di negeri Melaka. Setiap mukim ditadbir dan dijaga oleh seorang ketua yang dikenali sebagai Penghulu. Peranan utama Penghulu Mukim adalah dalam soal tanah. Lihat, C.O. 275/33, "Straits Settlements Annual Administration Report Malacca, 1887", Straits Settlements Annual Report, hlm. 379.

$8 \quad$ C.O. 275/33, "Straits Settlements Annual Administration Report Malacca, 1887", hlm. 379.

9 T. J. Newbold, Political and Statistical Account of the British Settlements in the Straits of Malacca, Vol. 1, Kuala Lumpur: Oxford University Press, 1971, hlm. 232. Lihat juga, T. Braddell, "Notes on Naning, with A Brief Notice of The Naning War", JIAEA, New Series, Vol. 1, 1856, hlm. 218.

10 Munsyi Abdullah, Hikayat Abdullah, Kuala Lumpur: Pustaka Antara Sdn. Bhd., 1997, hlm. 293. Lihat juga, T. J. Newbold, Political and Statistical Account of the British Settlements in the Straits of Malacca, hlm. 232; Horace St. John, The Indian Archipelago Its History and Present State, Vol. II, London: Longman, Brown, Green and Longmans, 1853, hlm. 105; T. Braddell, "Notes on Naning, with A Brief Notice of The Naning War", hlm. 218; Horace Hayman Wilson, The History of British India, from 1805-1835, Vol. III, London: James Madden, 8, Leadenhall Street, hlm. 330.

11 Munsyi Abdullah, Hikayat Abdullah, hlm. 293.

12 C.O. 275/35, "Straits Settlements Annual Administration Report Malacca for The Year 1888", hlm. 8.

13 T. Braddell, "Notes on Naning, with A Brief Notice of The Naning War", hlm. 218.

14 Shahba, Pesaka Naning, Kuala Pilah: Sentosa Store, 1951, hlm. 35.

15 Munsyi Abdullah, Hikayat Abdullah, hlm. 293-294. Lihat juga T. J. Newbold, Political and Statistical Account of the British Settlements in the Straits of Malacca, hlm. 238.

16 Zaharah Ismail, Perang Naning (1831-1832), Latihan Ilmiah, Jabatan Sejarah, Fakulti Sains Sosial dan Kemanusian, Universiti Kebangsaan Malaysia, 1987, hlm. 116.

17 Horace St. John, The Indian Archipelago Its History and Present State, Vol. II, hlm. 105.

18 Hj. Al-Sagap Hj. Lasim, Desa Warisan: Batang Melaka, Asal-Usul dan Kepimpinan Silam, 2007, hlm. 72

19 Hj. Zulkifli Hj. Mohd. Tahir, Penghulu Kawasan DUN Taboh Naning, Pejabat Daerah dan Tanah Alor Gajah (Bahagian Pembangunan), Wawancara, 9 November 2009.

20 Dol Bahar Mohamad, Beberapa Aspek Hukum Adat dan Pentadbiran di Naning (1900-1941): Unsur Demokrasi, Latihan Ilmiah, Jabatan Sejarah, Fakulti Sains Sosial dan Kemanusian, Universiti Kebangsaan Malaysia, 1986, hIm. 105.

21 Zainal Kling, "Adat Minangkabau di Naning (Melaka): Beberapa Perubahan Struktur", dalam Abdul Latif Abu Bakar, Sejarah di Selat Melaka, hlm. 89.

22 SUK Negeri Selangor, Adat Naning, Short-Notes by Mr. A. B. Ramsay Relating to the Naning Custom in Malacca, R. C. Selangor 567/1946. 
23 Horace St. John, The Indian Archipelago Its History and Present State, Vol. II, hlm. 105.

$24 \mathrm{Hj}$. Al-Sagap Hj. Lasim, Desa Warisan: Batang Melaka, Asal-Usul dan Kepimpinan Silam, hlm. 77.

25 Dol Bahar Mohamad, "Beberapa Aspek Hukum Adat dan Pentadbiran di Naning (1900-1941): Unsur Demokrasi", hlm. 105-106.

26 Ibid., hlm. 109.

27 Hj. Al-Sagap Hj. Lasim, Desa Warisan: Batang Melaka, Asal-Usul dan Kepimpinan Silam, hlm. 77.

28 M. B. Hooker, Adat Laws in Modern Malaya: Land Tenure, Tradition Government and Religion, Kuala Lumpur: Oxford University Press, 1972, hlm. 97.

29 SS Government Gazette, Government Notification-No. 424, 18 Julai 1890, hlm. 1639.

30 Annual Report of the Straits Settlements 1855-1941, Vol. 5, 1901-1907, "Administration Report Malacca for the Year 1907", hlm. 630.

31 Zainal Kling، "Adat Minangkabau di Naning (Melaka): Beberapa Perubahan Struktur", dalam Abdul Latif Abu Bakar, Sejarah di Selat Melaka, hlm. 85-86.

32. Zainal Kling, Sistem Penghulu di Daerah Alor Gajah, Melaka, Latihan Ilmiah, Jabatan Pengajian Melayu, Fakulti Sastera dan Sains Sosial, Universiti Malaya, 1966, hlm. 42.

33 Ibid.

34 SSR. P. 3. Commissioner Young's Records, W. R. Young kepada J. Prinsep, Esq. Setiausaha Kerajaan, Genaral Department, 31 Disember 1838.

35 Abdullah Zakaria Ghazali, "Sejarah Ringkas Naning", Malaysia Dari Segi Sejarah, Bil. 27, 1999, hlm. 19.

36 T. Braddell, "Notes on Malacca", JIAEA, New Series, Vol. 1, 1856, hlm. 53.

37 Ibid., hlm. 55. Penghulu Mukim dikehendaki membuat salinan senaraisenarai tersebut dan menghantarnya ke Melaka setiap hari pertama dalam bulan Januari.

38 Hj. Al-Sagap Hj. Lasim, Desa Warisan: Batang Melaka, Asal-Usul dan Kepimpinan Silam, hlm. 78-79.

39 T. Braddell, "Notes on Malacca", hlm. 53.

40 C.O. 275/1, "Report on The Administration of The Straits Settlements, During The Year 1859-1860", hlm. 3.

41 SSR. P. 3. Commissioner Young's Records, W. R. Young kepada J. Prinsep, Esq. Setiausaha Kerajaan, Genaral Department, 31 Disember 1838.

42 Ibid.

43 Musa bin Bulat, "Pentadbiran di Masyarakat Naning: Dahulu dan Sekarang", dalam Khoo Kay Kim (ed.), Melaka Dahulu dan Sekarang. hlm. 169. 
44 M. B. Hooker, Adat Laws in Modern Malaya: Land Tenure, Tradition Government and Religion, hlm. 98. Mahkamah Penghulu ini belum pernah ada di setiap negeri di Tanah Melayu sejak tahun 1940.

45 C.O. 275/1, "Report on The Administration of The Straits Settlements During The Year 1859-1860", hlm. 3.

46 T. J. Newbold, Political and Statistical Account of the British Settlements in the Straits of Malacca, hlm. 232.

47 SSR. P. 3. Commissioner Young's Records, W. R. Young kepada J. Prinsep, Esq. Setiausaha Kerajaan, Genaral Department, 31 Disember 1838.

$48 \quad$ T. Braddell, "Notes on Malacca", hlm. 53.

49 Penyewa disini bermaksud mereka yang menyewa tanah di Naning atau Melaka. Khidmat mereka boleh digunakan oleh Penghulu Mukim untuk menangkap pesalah sekiranya Mata-mata tidak dapat membantu.

$50 \quad$ T. Braddell, "Notes on Malacca", hlm. 53.

5 Hj. Al-Sagap Hj. Lasim, Desa Warisan: Batang Melaka, Asal-Usul dan Kepimpinan Silam, hlm. 78.

52 Ibid. Walaupun Penghulu Mukim diberi kepercayaan penuh oleh British untuk menjaga keselamatan mukim, namum terdapat juga kes Penghulu Mukim melakukan kesalahan jenayah. Seorang Penghulu Mukim telah memeras wang dari pemotong kayu dan beliau telah dibawa ke Mahkamah Jenayah di Melaka dan didapati bersalah. Beliau menerima hukuman penjara sembilan bulan dan kerja berat. Lihat, C.O. 275/2, "Straits Settlements Annual Administration Report Malacca for the Year 1864/1865", hlm. 18.

${ }^{53}$ Zainal Kling, “Adat Minangkabau di Naning (Melaka): Beberapa Perubahan Struktur", dalam Abdul Latif Abu Bakar, Sejarah di Selat Melaka, hlm. 89 .

54 Ibid.

55 Musa bin Bulat, "Pentadbiran di Masyarakat Naning: Dahulu dan Sekarang", dalam Khoo Kay Kim (ed.), Melaka Dahulu dan Sekarang, hlm. 169.

56 Zainal Kling, "Adat Minangkabau di Naning (Melaka): Beberapa Perubahan Struktur", dalam Abdul Latif Abu Bakar, Sejarah di Selat Melaka, hlm. 89.

57 T. J. Newbold, Political and Statistical Account of the British Settlements in the Straits of Malacca, hlm. 232.

58 C. O. 275/33, "Straits Settlements Annual Administration Report Malacca, 1887", hlm. 379.

59 Zainal Kling, "Adat Minangkabau di Naning (Melaka): Beberapa Perubahan Struktur", dalam Abdul Latif Abu Bakar, Sejarah di Selat Melaka, hlm. 89.

60 Musa bin Bulat, "Pentadbiran di Masyarakat Naning: Dahulu dan Sekarang", dalam Khoo Kay Kim (ed.), Melaka Dahulu dan Sekarang, hlm. 169 
61 Dol Bahar Mohamad, "Beberapa Aspek Hukum Adat dan Pentadbiran di Naning (1900-1941): Unsur Demokrasi", hlm. 109.

62 T. J. Newbold, Political and Statistical Account of the British Settlements in the Straits of Malacca, hlm. 261.

63 Zainal Kling, "Adat Minangkabau di Naning (Melaka): Beberapa Perubahan Struktur", dalam Abdul Latif Abu Bakar, Sejarah di Selat Melaka, hlm. 89.

64 Dol Bahar Mohamad, "Beberapa Aspek Hukum Adat dan Pentadbiran di Naning (1900-1941): Unsur Demokrasi", hlm. 109-110.

65 Zainal Kling, "Adat Minangkabau di Naning (Melaka): Beberapa Perubahan Struktur", dalam Abdul Latif Abu Bakar, Sejarah di Selat Melaka, hlm. 90.

66 Ibid., hlm. 89.

67 Haji Bokhari Haji Said, "Sejarah Penghulu di Melaka", Jurnal Sejarah Melaka, Bil 2, November 1977, hlm. 22.

68 M. B. Hooker, Adat Laws in Modern Malaya: Land Tenure, Tradition Government and Religion, hlm. 97.

69 Ibid., hlm. 98.

70 Haji Bokhari Haji Said, "Sejarah Penghulu di Melaka", hlm. 22.

71 Ibid.

72 SS Government Gazette, Government Notification-NO. 491, 25 September 1891, hlm. 2082-1083. Setakat tahun 1891, terdapat 78 orang Penghulu Mukim di Melaka iaitu 31 orang di peringkat pusat, 28 orang di daerah Alor Gajah dan 19 orang di daerah Jasin. Kesemua 78 orang Penghulu Mukim ini adalah pegawai kerajaan yang dilantik oleh British. Lihat, SS Government Gazette, Government Notification-NO. 491, 25 September 1891, hlm. 2082-1083.

73 SS Government Gazette, Government Notification-NO. 491, 25 September 1891, hlm. 2082.

74 Annual Report of the straits Settlements 1855-1941, Vol. 6, 1908-1914, "Administration Report Malacca for the Year 1909, hlm. 138.

75 Bagi mukim Tanjung Rimau, jawatan mata-mata yang terakhir dipegang oleh Encik Hassan bin Abdullah.

76 C.O. 275/55, "Administration Report on the Settlements of Malacca for the Year 1897", hlm. 311. Lihat juga, Annual Report of the Straits Settlements 1855-1941, Vol. 4, 1892-1900, "Administration Report Malacca for the Year 1897", hlm. 343.

$77 \mathrm{Hj}$. Al-Sagap Hj. Lasim, Desa Warisan: Batang Melaka, Asal-Usul dan Kepimpinan Silam, hlm. 82.

${ }_{78}$ SSR. U. 1. GLTRC., R. Ibbetson kepada Residen Konsular Melaka, 28 Jun 1832.

79 Hj. Al-Sagap $\mathrm{Hj}$. Lasim, Desa Warisan: Batang Melaka, Asal-Usul dan Kepimpinan Silam, hlm. 79-80.

80 C.O. 275/55, "Administration Report on the Settlements of Malacca for the Year 1897", hlm. 311. Lihat juga, Annual Report of the Straits Settlements 1855-1941, Vol. 4, 1892-1900, "Administration Report Malacca for the Year 1897", hlm. 343. 
81 J. R. Logan, "Five Days in Naning, with A Walk to The Foot of Gunong Datu in Rembau," JIAEA, Vol. III, 1849, hlm. 27.

82 Hj. Al-Sagap Hj. Lasim, Desa Warisan: Batang Melaka, Asal-Usul dan Kepimpinan Silam, hlm. 79-80.

83 Manuskrip, Notes on Naning Customs (Probably by Innes), sumber: Hervey, Dudley Francis Amdius, T.T. Selain Penghulu dan Mata-mata, pegawaipagawai lain yang dilantik juga dipilih mengikut giliran suku.

84 SSR. P. 3. Commissioner Young's Records, W. R. Young kepada J. Prinsep, Esq. Setiausaha Kerajaan, Genaral Department, 31 Disember 1838.

85 SS Government Gazette, Government Notification-No. 424, 18 Julai 1890, hlm. 1639.

86 Musa bin Bulat, "Pentadbiran di Masyarakat Naning: Dahulu dan Sekarang", dalam Khoo Kay Kim (ed.), Melaka Dahulu dan Sekarang, hlm. 169 .

87 SS Government Gazette, Government Notification-No. 424, 18 Julai 1890, hlm. 1639.

88 J. R. Logan, "Five Days in Naning, with A Walk to The Foot of Gunong Datu in Rembau", hlm. 26-27.

89 Ibid., hlm. 27.

90 Annual Report of the Straits Settlements 1855-1941, Vol. 2 1868-1883, "Administration Report Malacca for the Year 1882", hlm. 254.

91 C.O. 275/55, "Administration Report on the Settlements of Malacca for the Year 1897", hlm. 311. Lihat juga, Annual Report of the Straits Settlements 1855-1941, Vol. 4, 1892-1900, "Administration Report Malacca for the Year 1897", hlm. 343.

92 Ibid. Pada tahun 1879, sebanyak \$110 telah diperuntukkan untuk elaun kepada Penghulu. Elaun ini adalah hasil daripada jumlah kutipan daripada hasil cukai tanah. Lihat, Annual Report of the Straits Settlements 1855-1941, Vol. 2, 1868-1883, "Administration Report Malacca for the Year 1879", hlm. 432. Elaun ini terus meningkat dari tahun ke tahun. Pada tahun 1888, sebanyak $\$ 353$ telah diperuntukkan untuk elaun kepada Penghulu. Lihat, C.O. 275/35, "Straits Settlements Annual Administration Report Malacca for The Year 1888", hlm. 8. Manakala pada tahun 1890, sebanyak $\$ 250$ diperuntukkan untuk elaun kepada Penghulu. Lihat, C.O. 275/40, "Straits Settlements Annual Administration Report Malacca for The Year 1890", hlm. 6. Lihat juga, Annual Report of the Straits Settlements 1855-1941, Vol. 3, 1884-1891, "Administration Report Malacca for the Year 1890", hlm. 568. Pada tahun 1895 , sebanyak $\$ 437.10$ diperuntukkan untuk membayar gaji dan elaun kepada Penghulu. Peruntukkan gaji dan elaun kepada Penghulu ini meningkat kepada $\$ 1,796.77$ pada tahun 1896. Lihat, C.O. 275/53, "Straits Settlements Administration Report Malacca for The Year 1896", hlm. 255. Lihat juga, Annual Report of the Straits Settlements 1855-1941, Vol. 4, 1892-1900, "Administration Report Malacca for the Year $1896^{\prime \prime}, \mathrm{hlm}$. 287. Peningkatan peruntukan untuk 
gaji dan elaun Penghulu pada tahun 1896 menyebabkan peningkatan pengeluaran yang agak besar pada tahun ini.

93 C.O. 275/55, "Administration Report on the Settlements of Malacca for the Year 1897", hlm. 311. Lihat juga, Annual Report of the Straits Settlements 1855-1941, Vol. 4, 1892-1900,"Administration Report Malacca for the Year 1897", hlm. 343.

94 Ibid.

95 C.O. 275/70, "Administration Report on the Settlements of Malacca for the Year 1904", hlm. 157.

96 Ibid.

97 Haji Bokhari Haji Said, "Sejarah Penghulu di Melaka", hlm. 22. Semasa pendudukan Jepun (1942-1945), tugas dan peranan Penghulu Mukim adalah sama seperti zaman pemerintahan British. Gaji yang dibayar juga adalah sama tetapi tugasnya bertambah berat kerana menghadapi zaman perang. Ketika British mengambil semula pemerintahan Tanah Melayu pada tahun 1946, pelantikan Penghulu Mukim diteruskan dan pindaan gaji dibuat sehingga meningkat $\$ 127.00$ sebulan.

98 Annual Report of the Straits Settlements 1855-1941, Vol. 5, 1901-1907, "Administration Report Malacca for the Year 1905", hlm. 431.

99 Annual Report of the straits Settlements 1855-1941, Vol. 5, 1901-1907, "Administration Report Malacca for the Year 1907", hlm. 630.

100 Annual Report of the straits Settlements 1855-1941, Vol. 6, 1908-1914, "Administration Report Malacca for the Year 1908", hlm. 42.

101 Pembayaran bonus kepada Penghulu Mukim adalah berdasarkan kepada 90 peratus penilaian mukim yang telah dibayar. Namun, pada tahun 1910 pembayaran bonus kepada Penghulu Mukim pada tahun ini tidak dibayar sehingga 90 peratus daripada penilaian mukim yang telah dibayar. Lihat, Annual Report of the Straits Settlements 1855-1914, Vol. 6, 1908-1914, "Administration Report Malacca for the Year 1910", hlm. 228. Pada tahun 1914, Penghulu Mukim di daerah Alor Gajah telah mengecewakan kerajaan kerana gagal menjalankan pekerjaan dengan baik dan dalam beberapa kes mereka gagal untuk mendapatkan bonus. Lihat, Annual Report of the Straits Settlements 1855-1941, Vol. 6, 1908-1914, "Administration Report Malacca for the Year 1914", hlm. 593.

102 Annual Report of the straits Settlements 1855-1941, Vol. 6, 1908-1914, "Administration Report Malacca for the Year 1912", hlm. 429.

103 Annual Report of the Straits Settlements 1855-1941, Vol. 2, 1868-1883, "Administration Report Malacca for the Year 1882", hlm. 611.

104 C.O. 275/55, "Administration Report on the Settlements of Malacca for the Year 1897", hlm. 311. Lihat juga, Annual Report of the Straits Settlements 1855-1941, Vol. 4, 1892-1900, "Administration Report Malacca for the Year 1897", hlm. 343. 